\title{
New Capability at ORNL: High- Precision Uranium Titration
}

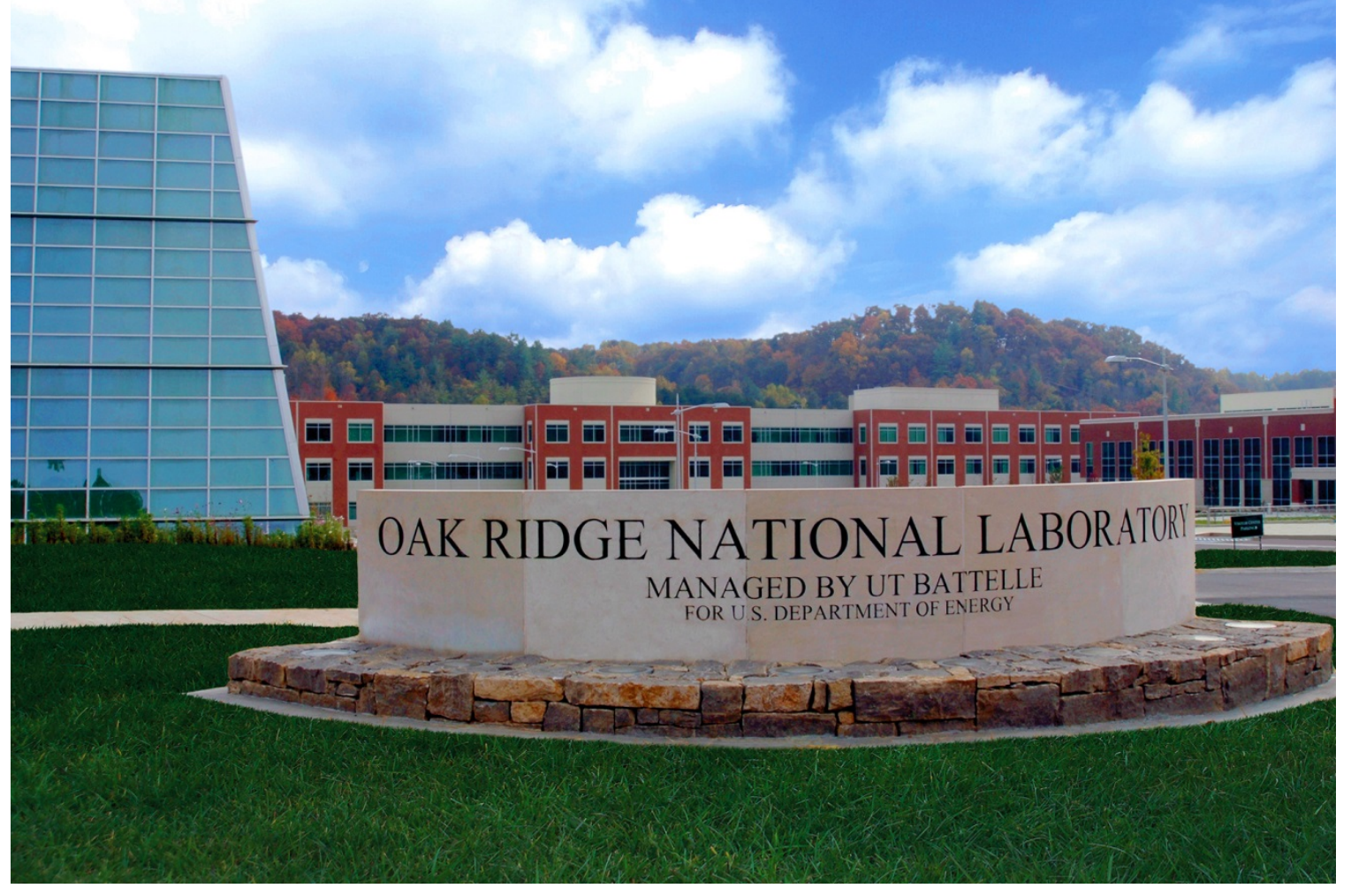

Kayron Rogers

Ben Roach

Jenn Parikh

Haley Wightman

Ralph Ilgner

Marc Chattin

Cole Hexel

Joseph Giaquinto

February 2021 


\title{
DOCUMENT AVAILABILITY
}

Reports produced after January 1, 1996, are generally available free via US Department of Energy (DOE) SciTech Connect.

Website www.osti.gov

Reports produced before January 1, 1996, may be purchased by members of the public from the following source:

\author{
National Technical Information Service \\ 5285 Port Royal Road \\ Springfield, VA 22161 \\ Telephone 703-605-6000 (1-800-553-6847) \\ TDD 703-487-4639 \\ Fax 703-605-6900 \\ E-mail info@ntis.gov \\ Website http://classic.ntis.gov/
}

Reports are available to DOE employees, DOE contractors, Energy Technology Data Exchange representatives, and International Nuclear Information System representatives from the following source:

Office of Scientific and Technical Information

PO Box 62

Oak Ridge, TN 37831

Telephone 865-576-8401

Fax 865-576-5728

E-mail reports@osti.gov

Website https://www.osti.gov/

This report was prepared as an account of work sponsored by an agency of the United States Government. Neither the United States Government nor any agency thereof, nor any of their employees, makes any warranty, express or implied, or assumes any legal liability or responsibility for the accuracy, completeness, or usefulness of any information, apparatus, product, or process disclosed, or represents that its use would not infringe privately owned rights. Reference herein to any specific commercial product, process, or service by trade name, trademark, manufacturer, or otherwise, does not necessarily constitute or imply its endorsement, recommendation, or favoring by the United States Government or any agency thereof. The views and opinions of authors expressed herein do not necessarily state or reflect those of the United States Government or any agency thereof. 
Nuclear Analytical Chemistry

\title{
NEW CAPABILITY AT ORNL: HIGH-PRECISION URANIUM TITRATION
}

\author{
Kayron Rogers \\ Ben Roach \\ Jenn Parikh \\ Haley Wightman \\ Ralph Ilgner \\ Marc Chattin \\ Cole Hexel \\ Joseph Giaquinto
}

February 2021

Prepared by OAK RIDGE NATIONAL LABORATORY

Oak Ridge, TN 37831-6283

managed by

UT-BATTELLE, LLC

for the

US DEPARTMENT OF ENERGY

under contract DE-AC05-00OR22725 



\section{CONTENTS}

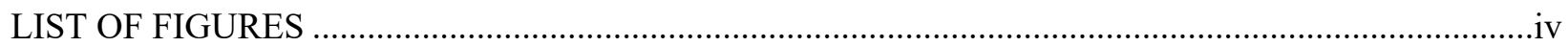

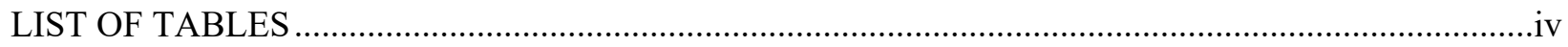

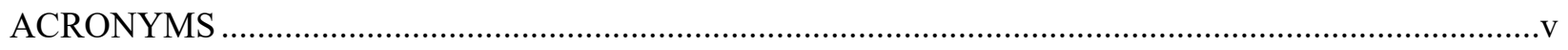

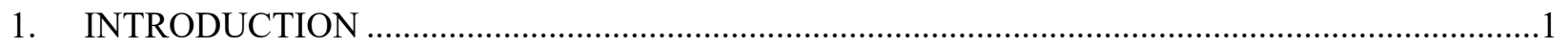

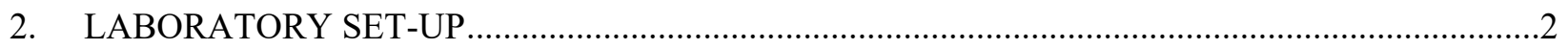

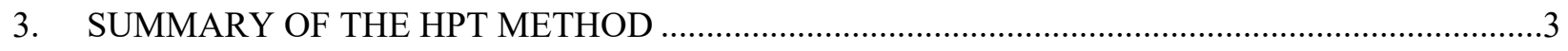

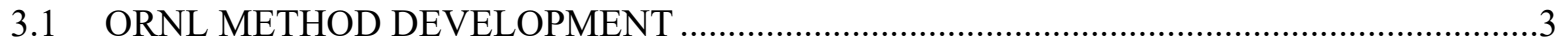

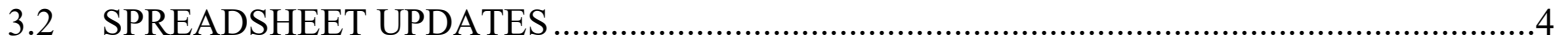

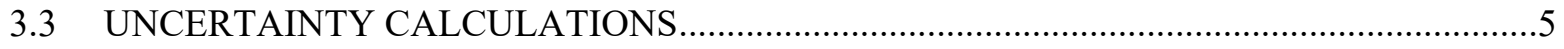

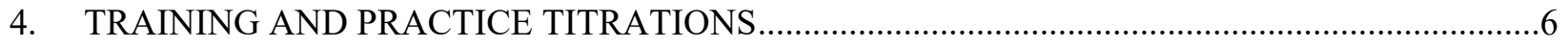

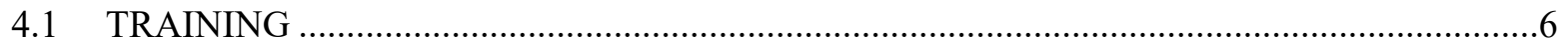

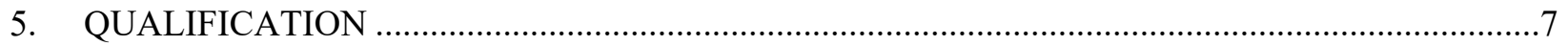

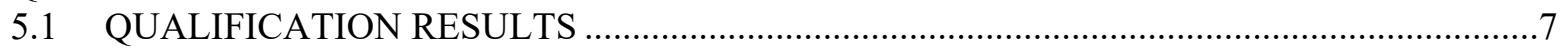

5.2 ASSESSMENT AND COMMITMENT TRACKING SYSTEM ..........................................

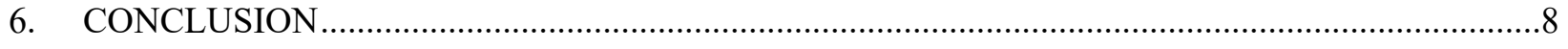

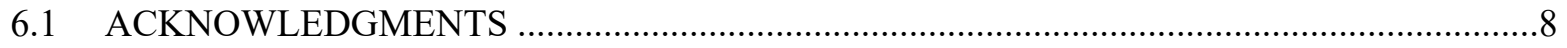

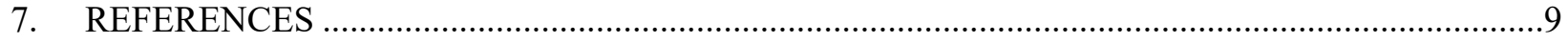

APPENDIX A. TRAINING AND QUALIFICATION DOCUMENTS …............................................ 


\section{LIST OF FIGURES}

Figure 1. Photo of the HPT laboratory, Lab 218 in Building 4501 at ORNL, captured in June 2020.

Figure 2. Major contributors to the uncertainty of a single HPT measurement when NIST SRM

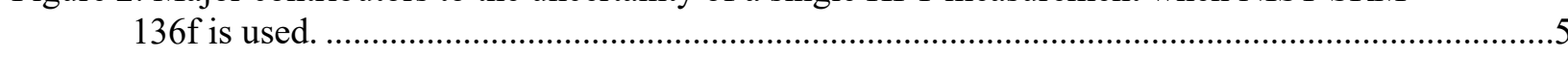

Figure 3. Trainees observe NBLPO personnel perform an HPT titration. ..............................................6

Figure 4. High Precision Titration Qualification Results. .......................................................................

\section{LIST OF TABLES}

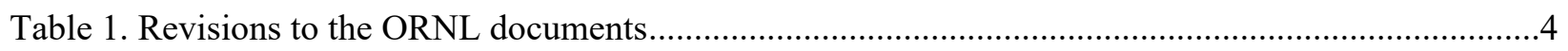

Table 2. List of participants in September 2019 HPT Training...............................................................6 


\section{ACRONYMS}

ACTS Assessment and Commitment Tracking System

AM

CRM

analytical method

CSD

certified reference material

Chemical Sciences Division

GUM

HPT

Guide to Uncertainty in Measurement

NAC

high-precision titration

NBL

Nuclear Analytical Chemistry

NBLPO

ORNL

$\mathrm{RM}$

New Brunswick Laboratory

New Brunswick Laboratory Program Office

Oak Ridge National Laboratory

reference material 


\section{INTRODUCTION}

Destructive analytical measurements establish a nuclear facility's nuclear material inventory and inventory differences for Nuclear Material Accountancy and Control. A nuclear laboratory's ability to perform accurate high-precision analytical measurements is key for tracking large inventories within a facility's material balance areas and during production to track material movement through dynamic processes. For uranium, these measurements are made by using several established high-precision measurement protocols. These include isotope dilution mass spectrometry, gravimetry, and potentiometric titrations. Whatever measurement technique a nuclear lab chooses to use, reference materials (RMs) with certified attributes and accompanying uncertainties are used to calibrate measurement systems, and are the cornerstone for accurate results. In addition to calibration, RMs provide for metrological traceability, are used for method development and validation, and thus provide critical evaluations of the appropriateness and performance of analytical processes used. Evaluations may include validation that a method is fit-for-purpose, quantification of systematic and random biases, and the evaluation of long-term and short-term performance metrics. High-precision measurement techniques require that measured attributes be certified to a high degree of precision in the RMs used - ultimately, to a higher degree than that of the measurement technique itself.

The US authority on the production of special nuclear material Certified Reference Materials is the NBL Program Office (NBLPO), formally known as New Brunswick Laboratory (NBL). The NBLPO is responsible for the sales and distribution of existing NBL certified reference materials (CRMs) and for the production of the next generation of nuclear RMs. To accomplish its mission, NBLPO is establishing key base capabilities within the DOE laboratory complex that formerly existed at the NBL laboratory. The Nuclear Analytical Chemistry (NAC) section within the Chemical Sciences Division (CSD) at Oak Ridge National Laboratory (ORNL) is currently working with NBLPO to set up laboratory and measurement capabilities to provide measurements and capabilities for production and/or recertification of existing and future CRMs for uranium assay. The NBL-developed high-precision titration (HPT) method is a critically-evaluated, extremely precise and accurate primary method utilized for the determination of uranium content in a variety of uranium materials. The HPT method, combined with detailed balance weighing protocols, provides for an analytical methodology that is unsurpassed in precision and one in which all sources of error have been evaluated, a requirement of CRM certification. HPT capability within the United States was lost with the closure of the labs at NBL. The NAC has been collaborating with NBLPO to stand up and demonstrate the capability to perform uranium assay via HPT at ORNL. HPT can produce results with an expanded uncertainty of approximately $0.01 \%$ for pure uranium compounds, with typical precisions of $<0.006 \%$.

The major tasks required to stand up the method at ORNL were the refurbishment of a dedicated lab and equipment setup, procedure development, analyst training, establishing method-specific quality assurance, and qualification of an analyst to perform the method. This report summarizes these tasks, outlines the documents drafted, and gives the outcome of the qualification titrations. 


\section{LABORATORY SETUP}

The NAC manages several laboratory spaces in Building 4501 for its analytical projects and programs. Room 218 is a $308 \mathrm{ft}^{2}$ laboratory space that contained legacy equipment, some contaminated with radioactivity, for projects no longer supported by the Radioactive Materials Analytical Laboratory group. The laboratory is designated as a C-zone space and has two chemical fume hoods, one 8-foot and one 4foot, approved for radiological work. For repurposing into a lab dedicated to HPT, the space was deemed suitable to be cleaned, refurbished, and then equipped. The greatest challenge to the repurposing effort was the disposal of a legacy high-performance liquid chromatography system housed in the 8-foot hood. The instrument was used to perform high-pressure separations of highly radioactive spent nuclear fuel specimens and was internally contaminated. The NAC worked closely as a team with ORNL Waste Services Division and Nuclear and Radiological Protection Division to create a waste disposal plan and Radiological Worker Permit for removal and packaging of the instrument. Once the room was cleared of unusable equipment, the laboratory floors were cleaned, a new output air filter bracket and air filter were installed, and the 8-foot chemical fume hood was cleaned and painted.

The lab was then equipped and set up for the HPT method. The following are highlights of the items purchased and installed:

- a six-place balance with a 22-gram capacity from Mettler Toledo

- a five-place balance with a 220 g capacity (Mettler Toledo, provided by NBLPO)

- a two-place top loader balance, capacity $>5000 \mathrm{~g}$, from Mettler Toledo

- a hot plate with $\pm 2{ }^{\circ} \mathrm{C}$ surface gradient

- a drying oven

- an OHAUS $\mathrm{pH} / \mathrm{mV}$ meter

- four saturated calomel electrodes from OHAUS (for later use and safekeeping)

- A platinum ( $99.95+\%$ purity) wire electrode (3 ft)

- a temperature-controlled refrigerator

- a rod cutter for cutting uranium metal

- a new computer for real-time data processing

Figure 1 is a photograph of the updated laboratory space.

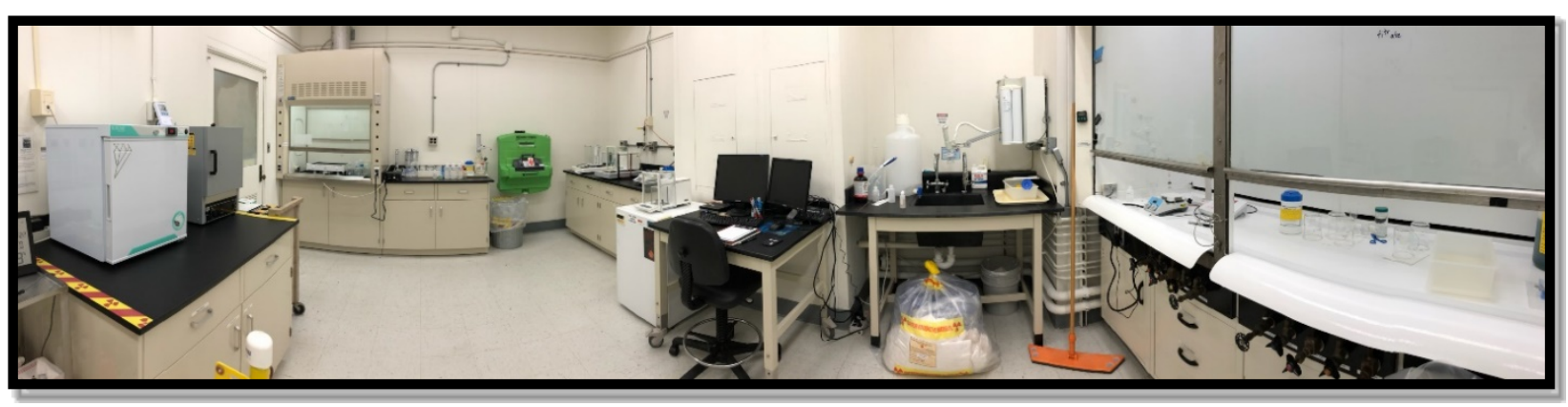

Figure 1. Photo of the HPT laboratory, Laboratory 218 in Building 4501 at ORNL, captured in June 2020. 


\section{SUMMARY OF THE HPT METHOD}

HPT is a scaled-up variant of the Davies \& Gray titrmetric method, which is a redox titration completed to a potentiometric endpoint. An oxidizing agent, in this case potassium dichromate, stoichiometrically oxidizes the uranium species. The "high-precision" prefix lends itself to the relatively large sample mass (i.e., 2.5-3.5 g U) used for the method; at this level, random deviations and biases due to titration chemistry are less pronounced. Uranium in phosphoric acid is reduced to U(IV) by ferrous sulfate. The excess $\mathrm{Fe}(\mathrm{II})$ is destroyed by molybdate-catalyzed oxidation with nitric acid. The nitrous acid produced in this reaction, which with time would reduce $\mathrm{Fe}(\mathrm{III})$ to again form $\mathrm{Fe}(\mathrm{II})$, is destroyed by reduction with sulfamic acid. The sample is diluted with water, and vanadyl sulfate is added to increase the rate of the titration reaction. $\mathrm{U}(\mathrm{IV})$ is titrated with a potassium dichromate primary standard by adding most of the potassium dichromate as a highly accurately weighed solid, followed by final titration, by mass, with a standard potassium dichromate solution. An endpoint for the chemical reaction has been previously experimentally determined at an $\mathrm{mV}$ reading of $600 \pm 15 \mathrm{mV}$. The reactions are as follows:

$$
\begin{aligned}
& \mathrm{U}(\mathrm{VI})+2 \mathrm{Fe}(\mathrm{II}) \stackrel{\mathrm{H}_{3} \mathrm{PO}_{4}}{\longrightarrow} \mathrm{U}(\mathrm{IV})+2 \mathrm{Fe}(\mathrm{III}) \\
& 2 \mathrm{Fe}(\mathrm{II})+\mathrm{HNO}_{3}+2 \mathrm{H}^{+} \stackrel{\mathrm{Mo}(\mathrm{VI})}{\longrightarrow} 2 \mathrm{Fe}(\mathrm{III})+\mathrm{HNO}_{2}+\mathrm{H}_{2} \mathrm{O} \\
& \mathrm{HNO}_{2}+\mathrm{NH}_{2} \mathrm{SO}_{3} \mathrm{H} \rightarrow \mathrm{H}_{2} \mathrm{SO}_{4}+\mathrm{N}_{2} \uparrow+\mathrm{H}_{2} \mathrm{O} \\
& 3 \mathrm{U}(\mathrm{IV})+2 \mathrm{Cr}(\mathrm{VI}) \stackrel{\mathrm{V}(\mathrm{IV})}{\longrightarrow} 3 \mathrm{U}(\mathrm{VI})+2 \mathrm{Cr}(\mathrm{III})
\end{aligned}
$$

\subsection{ORNL METHOD DEVELOPMENT}

Additionally, for the successful transition of the HPT method from NBLPO to ORNL, guidance documents for the method had to be drafted. With heavy reliance on procedures provided by NBLPO, ORNL staff produced four standard analytical methods, a work aid, and operating instructions. During the drafting process, revisions were made to adjust for NAC's capabilities; Table 1 lists the major revisions. The following documents were written, reviewed, and approved and are now being controlled using ORNL's Integrated Document Management System:

- CSD-AM-NCL-IN02, Determination of U-High Precision Titrimetric Method

- CSD-AM-NCL-IN03, Preparation and Verification or Standardization of Standard Potassium Dichromate Titrant

- CSD-AM-NCL-IN04, The Determination of Uranium in Iron (II) Reduction in Phosphoric Acid Followed by Chromium (VI) Titration

- CSD-AM-NCL-IN05, Preparation of Uranium Standard Solution

- NACIL-WA-002, Flaming Operations for Platinum Labware

- CSD-OI-NCL-001, Linearity Check of $\mathrm{pH} / \mathrm{mV}$ Meters 
Table 1. Revisions to the ORNL documents

\begin{tabular}{|c|c|}
\hline Document & Major revision \\
\hline $\begin{array}{l}\text { CSD-AM-NCL-IN02 } \\
\text { Revision } 0\end{array}$ & $\begin{array}{l}\text { The analysis for UF } 6 \text { was removed from the ORNL analytical method, where it } \\
\text { had existed in the NBLPO HPT procedure. }\end{array}$ \\
\hline $\begin{array}{l}\text { CSD-AM-NCL-IN02 } \\
\text { Revision } 0\end{array}$ & $\begin{array}{l}\text { Reference to uncertainty calculations were revised from an NBLPO internal } \\
\text { document (FOP-QA-40, Calculation of Uncertainties for Reportable } \\
\text { Measurements) to the more general Joint Committee for Guides in Metrology } \\
\text { 100:2008, Guide to the Expression of Uncertainty in Measurement. }\end{array}$ \\
\hline $\begin{array}{l}\text { CSD-AM-NCL-IN02 } \\
\text { Revision } 0\end{array}$ & $\begin{array}{l}\text { Readability specifications were added in the ORNL method for the thermometer, } \\
\text { hygrometer, and barometer. }\end{array}$ \\
\hline $\begin{array}{l}\text { CSD-AM-NCL-IN02 } \\
\text { Revision } 0\end{array}$ & $\begin{array}{l}\text { A clause was added for the drying oven to be equipped with a calibrated } \\
\text { thermometer with certificate on file. }\end{array}$ \\
\hline $\begin{array}{l}\text { CSD-AM-NCL-IN02 } \\
\text { Revision } 0\end{array}$ & $\begin{array}{l}\text { After phosphoric acid has been added to the solid uranium, and before } \\
\text { dissolution, the ORNL method revised } 2-3 \text { drops } 2 \% \mathrm{~K}_{2} \mathrm{Cr}_{2} \mathrm{O}_{7} \text { to } 150 \mathrm{uL} \text {; } \\
\text { changed 1-2 drops HF to } 200 \mu \mathrm{L} \text { HF. }\end{array}$ \\
\hline $\begin{array}{l}\text { CSD-AM-NCL-IN02 } \\
\text { Revision } 0\end{array}$ & $\begin{array}{l}\text { The NBLPO procedure called for a steam bath for dissolutions. The equipment } \\
\text { used for dissolution in the ORNL method is a hotplate. Specifically, this } \\
\text { statement was made in the ORNL method: "Heat the uncovered beaker on a hot } \\
\text { plate at } 100^{\circ} \mathrm{C} \text { until the sample has completely dissolved. Heat may be increased } \\
\text { to aid dissolution; do not exceed } 150^{\circ} \mathrm{C}\left(\mathrm{H}_{3} \mathrm{PO}_{4}, 85 \% \text { boiling point }=158^{\circ} \mathrm{C}\right) \text {. } \\
\text { Add additional HF dropwise as necessary to aid dissolution." }\end{array}$ \\
\hline $\begin{array}{l}\text { CSD-AM-NCL-IN02 } \\
\text { Revision } 0\end{array}$ & $\begin{array}{l}\text { The use of perchloric acid, } \mathrm{HClO}_{4} \text {, (for the fuming of } \mathrm{HNO}_{3} \text { dissolved samples) } \\
\text { was removed and replaced with the use of sulfuric acid }\left(\mathrm{H}_{2} \mathrm{SO}_{4}\right) \text {. This statement } \\
\text { was added: "This part of the procedure would need further testing. NBL } \\
\text { laboratory work subsided before work could be completed to see if a substitution } \\
\text { of } \mathrm{H}_{2} \mathrm{SO}_{4} \text { could be made for } \mathrm{H}_{3} \mathrm{PO}_{4} \text {, only initial work had been done (see 16.14)." } \\
\text { The statement references a study preformed at NBLPO in } 2010 \text {. }\end{array}$ \\
\hline \multirow[t]{2}{*}{$\begin{array}{l}\text { CSD-AM-NCL-IN02 } \\
\text { Revision } 0\end{array}$} & $\begin{array}{l}\text { The following calculation was added for the tabulation of air density, whereas the } \\
\text { NBLPO procedure used a different formula. }\end{array}$ \\
\hline & $d_{a}=\frac{0.348444 p-h(0.00252 t-0.020582)}{273.15+t}$ \\
\hline $\begin{array}{l}\text { CSD-AM-NCL-IN03 } \\
\text { Revision } 0\end{array}$ & $\begin{array}{l}\text { For the titrant that will be used in CSD-AM-NCL-IN04, the liquid potassium } \\
\text { dichromate can be verified with six Davies and Gray titrations or can be } \\
\text { standardized with a minimum of eight Davies and Gray titrations. The titrations } \\
\text { must be equally split between two independently prepared uranium standard } \\
\text { solutions. }\end{array}$ \\
\hline $\begin{array}{l}\text { CSD-OI-NCL-001 } \\
\text { Revision } 0\end{array}$ & $\begin{array}{l}\text { NBLPO used a voltage box that was calibrated by electronics metrology at } \\
\text { Argonne National Laboratory. ORNL uses a commercial } \mathrm{pH} / \mathrm{mV} \text { simulator that is } \\
\text { calibrated (traceable to NIST) by an outside company. }\end{array}$ \\
\hline
\end{tabular}

\subsection{SPREADSHEET UPDATES}

Data-reduction spreadsheets were shared with NAC from NBLPO. These included two controlled spreadsheets - (1) a spreadsheet for air density and buoyancy correction calculations made to the sample weight and potassium dichromate weight and (2) a spreadsheet for recording titration data and calculating the assay result. NAC separately prepared a spreadsheet for the preparation and verification of the liquid potassium dichromate. As a result of a recommendation during a quality assessment (see Section 5.2), with concurrence from NBLPO, the air density, buoyancy corrections, and titration data and calculations were combined into a single spreadsheet. This updated version was verified by hand calculation along 
with an independent verification by NBLPO staff. The update was applied for uranium metal, $\mathrm{UO}_{2}, \mathrm{UO}_{3}$, and $\mathrm{U}_{3} \mathrm{O}_{8}$ sample types.

\subsection{UNCERTAINTY CALCULATIONS}

The Guide to Uncertainty in Measurement (GUM) defines measurement uncertainty as a "parameter, associated with the result of a measurement, that characterizes the dispersion of the values that could reasonably be attributed to the measurand" [1]. A measurement typically has a mathematical model, or calculation, that relates "input values" to the final measurand. Uncertainties associated with these "input values" all contribute to the computation of the final measurand uncertainty. The GUM details a statistical approach to derive the standard uncertainty of the measurand by considering the uncertainty of the input values. In our case, this process is simplified through the use of GUM Workbench Software [2].

Development of a GUM Workbench can be quite involved, but it ultimately is beneficial to the analyst, lab management and sponsors, as it produces an uncertainty budget detailing the key input uncertainties that contribute to overall uncertainty. The uncertainty budget lists all the input values and their respective contributions to the total uncertainty in the form of a percentage. This is a tool that can be used to identify the major contributors to the uncertainty, and allow lab management and sponsors to focus efforts in areas that make significant improvements in the accuracy of measurement systems.. Although there are more than 30 input values in the HPT mathematical model, the major contributors to uncertainty of the uranium assay are the uncertainty of the certificatied value of the potassium dichromate and the weighing of sample and solid potassium dichromate (Figure 2).

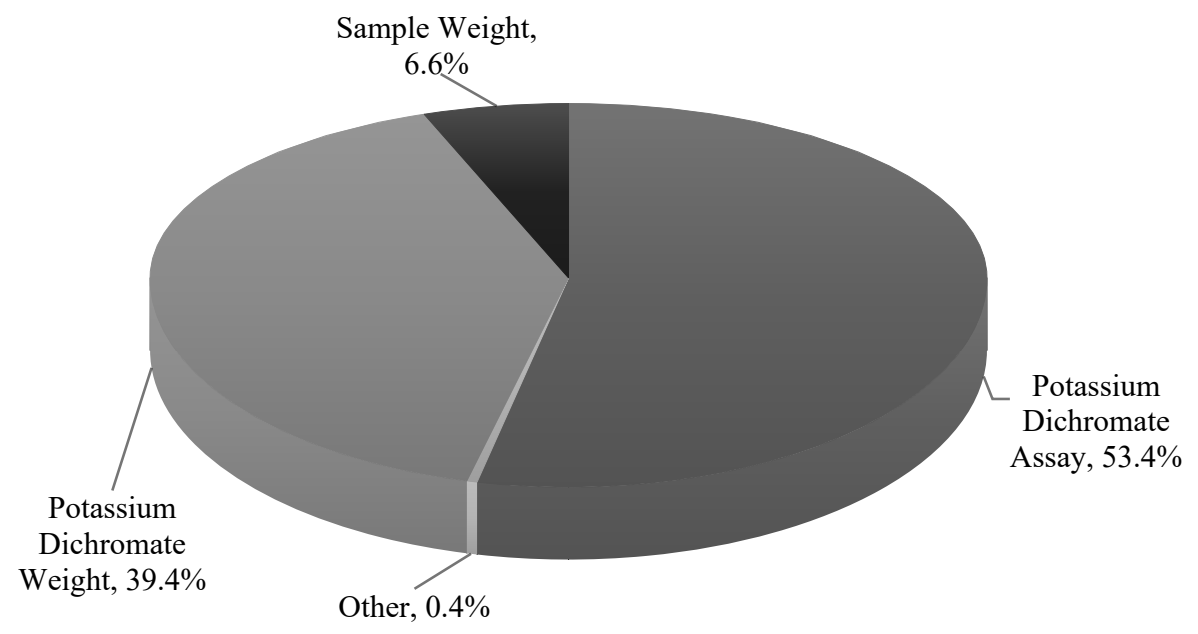

Figure 2. Major contributors to the uncertainty of a single HPT measurement when NIST SRM 136f is used. 


\section{TRAINING AND PRACTICE TITRATIONS}

\subsection{TRAINING}

During the week of September 9, 2019, NBLPO personnel conducted a training program at the new HPT lab at ORNL. The week-long training included hands-on laboratory work as well as a lecture. NBLPO staff shared knowledge of and demonstrated a linearity check of $\mathrm{pH}$ meters, use of data recording and reduction spreadsheets, platinum electrode flaming, preparation of standard potassium dichromate, uranium metal cleaning, weighing, and dissolution. After observing, the trainees all took their turns at practicing each task with guidance from the NBLPO experts. The trainers demonstrated one titration and then assisted and observed as the trainees titrated two to three samples each.

At the conclusion of the training, recommendations were made regarding how to move forward to qualify the method. Table 2 is a list of personnel involved and their roles in the training. Appendix A has a copy of the agenda for the training. A memorandum from the director of NBLPO for completion of the training is also included in Appendix A.

Table 2. List of participants in September 2019 HPT training.

\begin{tabular}{ll}
\hline \multicolumn{1}{c}{ Personnel } & \multicolumn{1}{c}{ Role } \\
\hline Haley Wightman & Secondary trainee at ORNL for the HPT method \\
Nancy Hui & NBLPO HPT expert \\
Ben Roach & Secondary trainee at ORNL for the HPT method \\
Kayron Rogers & Lead HPT and Davies and Gray analyst at ORNL \\
Anna Voeks & NBLPO HPT expert \\
\hline
\end{tabular}

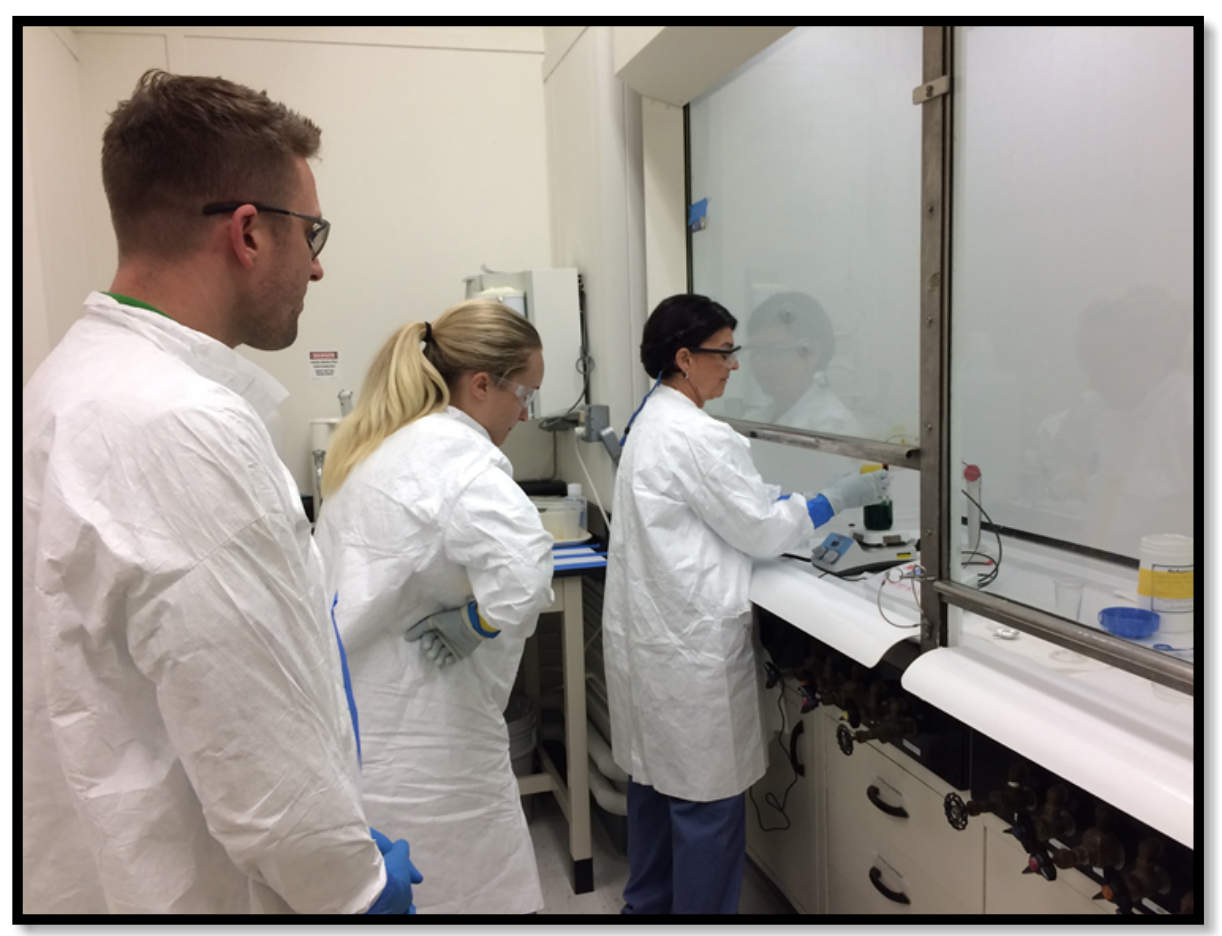

Figure 3. Trainees observe NBLPO personnel perform an HPT titration. From left to right: Ben Roach, Kayron Rogers, Anna Voeks. 


\section{QUALIFICATION}

\subsection{QUALIFICATION RESULTS}

To qualify and demonstrate proficiency for the method, an analyst is required to prepare and analyze five samples of CRM 112-A, the uranium metal assay standard from NBLPO. To meet the requirement, all acceptable titrations must fall within $0.012 \%$ of the certified value of the CRM and achieve a specific precision (defined as the standard deviation of the $\%$ relative differences, of $\leq 0.006 \%$ ). No more than one result may be removed from the five measurements as a result of handling error. In June 2020, analyst Kayron Rogers attempted to qualify for the HPT method (ORNL Analytical Method CSD-AM-NCLIN02) by analyzing five CRM 112-A samples. Results of the five titrations are plotted in Figure 4. The mean of the assay values was $0.999726 \mathrm{~g} \mathrm{U} / \mathrm{g}$ with a relative standard deviation of $0.002 \%$. These results fall well within the certified value for CRM 112-A of $0.99975 \pm 0.00006 \mathrm{~g} \mathrm{U} / \mathrm{g}$ metal. The results qualified one analyst for the method, and a Demonstration of Capability form was issued (see Appendix A).

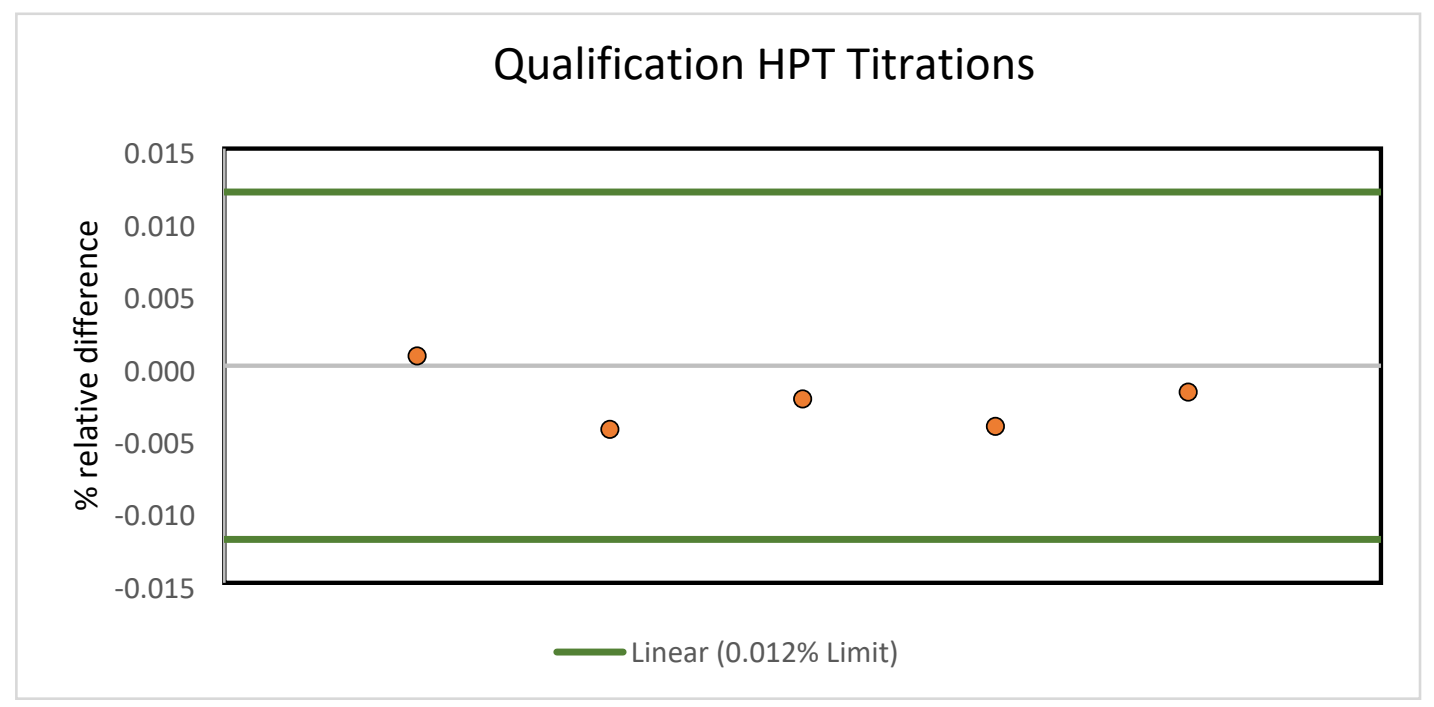

Figure 4. High-precision titration qualification results.

\subsection{ASSESSMENT AND COMMITMENT TRACKING SYSTEM}

The Assessment and Commitment Tracking System (ACTS) is a quality assurance measure at ORNL in which line managers and quality personnel assess tasks performed at all work levels to identify deficiencies or improvements in programs, systems or processes. During qualification, the NAC section head and quality representative assessed potassium dichromate weighing, uranium metal dissolution, and qualification titrations. This review included an in-laboratory observation during the potassium dichromate weighing and qualification titrations, as well as a review of spreadsheets used for data analysis.

Findings from the assessments identified one non-compliance: "Is software used tested, validated and approved for the calculations performed?" To address this issue, hand calculations for data reduction were documented and an independent verification of the spreadsheet was performed by NBLPO. Spreadsheet updates mentioned in Section 3.3 of this report were a result of an issue filed by the ACTS program. Once the requirements were satisfied, the ACTS issue was closed and the quality assessment was complete. 


\section{CONCLUSION}

The NAC has completed a successful collaboration with NBLPO to establish a unique capability to perform the HPT method for the certification of existing and future uranium CRMs at ORNL. This capability is currently unique to ORNL and provides the NBL PO the ability to produce the next generation of uranium CRM's utilizing the expertise and ability developed through this collaboration. The method is highly accurate and reproducible for the determination of uranium content in metal or oxide forms. The development of this capability positions the NAC section to contribute to measurements that provide attribute values to critical uranium certified RMs under the direction of NBLPO.

Details of the HPT lab and procedure development and the training were presented at the $60^{\text {th }}$ Institute of Nuclear Materials Management Annual Meeting in Palm Desert, California in July 2019, accompanied by a conference proceeding.

- Rogers, K., Roach, B., Giaquinto, J., Ilgner, R., Wightman, H., Chattin, M., Hexel, C., Voeks, A., Hui, N., Mason, P. "Establishing a High-Precision Titrimetric Laboratory at Oak Ridge National Laboratory to Support the NBL Program Office's Mission," Institute of Nuclear Materials Management 60 ${ }^{\text {th }}$ Annual Meeting, Palm Desert, California, July 14-19, 2019.

\subsection{ACKNOWLEDGMENTS}

This work was funded by the US DOE, National Nuclear Security Agency's NBL Program Office. NBLPO director Peter Mason identified ORNL as the first laboratory to establish the method and capability. Nancy Hui, Anna Voeks, Alma Stiffin, and Paul Croatto provided information and training that were invaluable to the success of the project. Robert Watters and Michael Holland reviewed spreadsheets and procedures and provided advice throughout the process. Lisa Duncan from the Nuclear and Radiological Protection Division provided assistance during the laboratory cleanup. Jimmy Selph from Transportation and Waste Management Division worked with NAC to develop a plan and documentation for disposal of legacy equipment for the lab refurbishment. 


\section{REFERENCES}

1. Evaluation of Measurement Data-Guide to the Expression of Uncertainty in Measurement, JCGM 100:2008, Joint Committee for Guides in Metrology, 2008.

2. GUM Workbench Professional Version 2.4 [Computer Software] Metrodata, http://www.metrodata.de/ver24 en.html 
APPENDIX A. TRAINING AND QUALIFICATION DOCUMENTS 



\section{A.1 TRAINING AGENDA}

\section{OAK RIDGE}

National Lahoratory

\section{AGENDA}

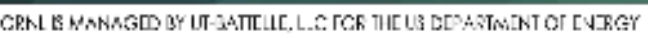

HPT Meeting Agenda

\begin{tabular}{|c|c|c|c|}
\hline \multirow{2}{*}{$\begin{array}{l}\text { Event contact } \\
\text { Time }\end{array}$} & \multicolumn{3}{|c|}{$\begin{array}{l}\text { Kayron Rogers, 865-574-2444 (office); 931-704-2514 (mobile); } \\
\text { rogerskt@ornl.gov }\end{array}$} \\
\hline & Event & Aftendees & Place \\
\hline \multicolumn{4}{|c|}{ Monday, September 9, 2019} \\
\hline $8: 30-9: 00 \mathrm{am}$ & $\begin{array}{l}\text { Meet at Visitor Center, Badge In, Transport to } \\
1005 \text { Room } 84\end{array}$ & $\begin{array}{l}\text { Kayron Rogers, Anna Voeks, } \\
\text { Nancy Hui }\end{array}$ & Visitor's Center \\
\hline $9: 00-10: 00 \mathrm{am}$ & $\begin{array}{l}\text { Progress Update } \\
\text { Discuss Plan for the Week }\end{array}$ & $\begin{array}{l}\text { Kayron Rogers, Anna Voeks, } \\
\text { Nancy Hui, } \\
\text { Haley Heese, Ben Roach } \\
\text { (referred to os All) }\end{array}$ & $\begin{array}{l}\text { Building } 1005 \\
\text { Room } 84\end{array}$ \\
\hline 10:00-10:20am & Break & & \\
\hline 10:20am-11:30am & $\begin{array}{l}\text { Talk Procedures } \\
\text { Set up notebook pages for U Metal } \\
\text { Dissolution }\end{array}$ & All & $\begin{array}{l}\text { Building } 1005 \\
\text { Room } 84\end{array}$ \\
\hline $11: 30 \mathrm{am}-12: 45 \mathrm{pm}$ & Lunch & All & ORNL Cafeteria \\
\hline $12: 45-1: 00 \mathrm{pm}$ & Transport to Training & $\begin{array}{l}\text { Haley Heese, } \\
\text { Anna Voeks, } \\
\text { Nancy Hui }\end{array}$ & \\
\hline 1:00-2:00pm & Site Specific Training & $\begin{array}{l}\text { Ed Turnington } \\
\text { Anna Voeks } \\
\text { Nancy Hui }\end{array}$ & \\
\hline $2: 00-2: 30 \mathrm{pm}$ & $\begin{array}{l}\text { Transport to 4501, Building Tour, Changing. } \\
\text { RWP Coverage }\end{array}$ & $\begin{array}{l}\text { Lisa Duncan } \\
\text { All }\end{array}$ & Building 4501 \\
\hline $2: 30-5: 00 \mathrm{pm}$ & $\begin{array}{l}\text { Enter Lab, Lab Tour } \\
\text { Discuss Metal Dissolution } \\
\text { (Weigh and dissolve uranium metal. Anna demonstrates } \\
\text { one pieoe. Kayron and Haliey do one pieoe eaoh. Enter } \\
\text { data in spreadsheets for buoy ancy comection and } \\
\text { fitrafion. Explain spreadsheet use os necessary. Review } \\
\text { spreadsheets for previously dissolved metal]. }\end{array}$ & All & 4501 Lab 218 \\
\hline
\end{tabular}




\section{OE OAK RIDGE}

National Laboratory

AGENDA

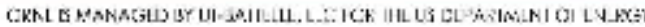

\section{HPT Meefing Agenda}

\begin{tabular}{|c|c|c|c|}
\hline Time & Event & Attendees & Place \\
\hline \multicolumn{4}{|c|}{ Tuesday, September 10, 2019} \\
\hline $8: 30-10: 00 \mathrm{am}$ & $\begin{array}{l}\text { Questions/Review on metal dissolution. Set up } \\
\text { notebook pages for weighing potassium } \\
\text { dichromate. }\end{array}$ & All & 4501 Lab 218 \\
\hline 10:00-10:15am & Break & & \\
\hline $10: 15 \mathrm{am}-12: 00 \mathrm{pm}$ & $\begin{array}{l}\text { Weigh potassium dichromate for all metal } \\
\text { samples, except two for gel demo. Anna } \\
\text { demonstrates; Kayron and Haley follow. }\end{array}$ & All & 4501 Lab 218 \\
\hline 12:00-1:00pm & Lunch & All & ORNL Cafeteria \\
\hline $1: 00-4: 30 p m$ & $\begin{array}{l}\text { Reviaw Kmym's Standard Dichromate prep } \\
\text { (Nancy). Continue weighing potassium } \\
\text { dichromate. Enter data in spreadsheets for } \\
\text { buoyancy correction and titration. }\end{array}$ & All & 4501 Lab 218 \\
\hline \multicolumn{4}{|c|}{ Wednesday, September 11, 2019} \\
\hline $8: 30-10: 00 \mathrm{am}$ & Set up notebook pages for titrations. & All & 4501 Lab 218 \\
\hline 10:00-10:15am & Break & & \\
\hline 10:15am-12-00pm & $\begin{array}{l}\text { Perform High Precision Titrations. Anna } \\
\text { demonstrates; Kayron and Haley follow. }\end{array}$ & All & 4501 Lab 218 \\
\hline 12:00-1:00pm & Lunch & All & ORNL Cafeteria \\
\hline 1:00-4:30pm & $\begin{array}{l}\text { Questions/Review } \\
\text { Continue High Precision Titrations } \\
\text { Questions/Review/Spreadsheets }\end{array}$ & All & 4501 Lab 218 \\
\hline
\end{tabular}

\section{HPT Meeting Agenda}


" OAK RIDGE

National Laboratory

AGENDA

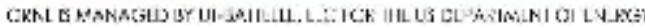

\begin{tabular}{|c|c|c|c|}
\hline Time & Event & Attendees & Place \\
\hline \multicolumn{4}{|c|}{ Thursday, September 12, 2019} \\
\hline $8: 30-10: 00 \mathrm{am}$ & $\begin{array}{l}\text { Questions/Review } \\
\text { Continue High Precision Titrations; Anna } \\
\text { demonstrates gel formation }\end{array}$ & All & 4501 Lab 218 \\
\hline 10:00-10:15am & Break & & \\
\hline 10:15am-12:00pm & Morning Continues & All & 4501 Lab 218 \\
\hline $12: 00-1: 00 \mathrm{pm}$ & Lunch & All & ORNL Cafeteria \\
\hline 1:00-4:30pm & $\begin{array}{l}\text { Questions/Review } \\
\text { Continue High Precision Titrations } \\
\text { Finalize titration spreadsheet }\end{array}$ & All & 4501 Lab 218 \\
\hline \multicolumn{4}{|c|}{ Friday, September 13, 2019} \\
\hline 8:30-10:00am & Questions/Review & All & 4501 Breakroom \\
\hline 10:00-10:15am & Break & & \\
\hline 10:15am-12:00pm & In lab, Questions/Review & All & 4501 Lab 218 \\
\hline 12:00-1:00pm & Lunch & All & ORNL Cafeteria \\
\hline 1:00-3:00pm & $\begin{array}{l}\text { Discuss Results } \\
\text { (136f, other topics as needed) }\end{array}$ & All & 4501 Breakroom \\
\hline
\end{tabular}




\section{A.2 MEMORANDUM FOR TRAINING FROM NBLPO}
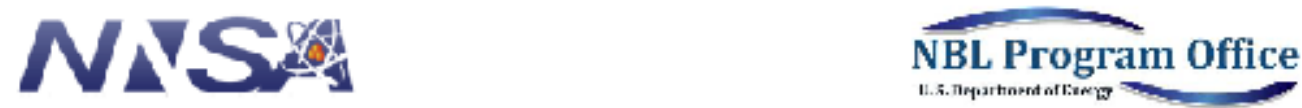

Memorandum

To: Oak Ridge National Laboratory

From: Peter Mason, NBL Program Office

Date: December 12, 2019

Re: Completion of High Precision Titration Training

This memo is to document the successful completion of training for three Oak Ridge National Laboratory (ORNL) chemists. This training was conducted the week of September 9-13, 2019 at ORNL. The trainers were Nancy Hui, NBL Program Office (NBL PO) chemist and Anna Voeks, former NBL Program Office chemist and current contractor to the NBL PO. The trainees were Kayron Rogers, Ben Roach and Haley Wightman.

The training consisted of lecture and hands-on demonstration including the trainee's each completing a number of titrations. The training included the following NBL PO procedures and techniques:

- Linearity check of pH meters

- Use of buoyancy correction and associated spreadsheet

- Electrode flaming procedure

- High precision titrimetric method, including all calculations

- Preparation of standard potassium dichromate

- Uranium metal cleaning, weighing and dissolution

The NBL PO trainers concluded that the ORNL participants demonstrated adequate ability and understanding of the methods and that ORNL should proceed with implementing the methods and eventual formal qualification of their chemists.

Peter Mason

NBL Progam Office Director

NA-121 Office of Stockpile Production Integration

US Department of Energy/National Nuclear Security Administration

Cc: J. Giaquinto, ORNL

K. Rogers, ORNL

To file, NBL PO 


\title{
A.3 DEMONSTRATION OF CAPABILITY FORM
}

\section{OAK RIDGE NATIONAL LABORATORY MANAGED BY UT-BATTELLE FOR THE US DEPARTMENT OF ENERGY}

\author{
Physical Sciences Directorate \\ Chemical Sciences Division
}

Nuclear Analytical Chemistry and Isotopics Laboratories Group

\section{Demonstration of Capability}

This document is to certify that Kayron Rogers has demonstrated acceptable performance in the analysis of Uranium (g/g) using procedure "Determination of U-High Precision Titrimetric Method", CSD-AM-NCL-IN02. This demonstration of capability involved the preparation and analysis of at least 5 known laboratory controls, prepared and analyzed in the same manner as samples. The laboratory controls were prepared using NISTtraceable material, NBL, CRM112-A, processed per approved analytical methods, in accordance with the NACIL Quality Assurance Plan (QAP-X-96-CSD/RML-001) and reported below. Acceptability is determined by calculating the percent recovery as well as the relative percent difference or standard deviation between replicates as applicable. Project or procedural requirements shall be documented as acceptance criteria.

Date of Analysis: 06/18/2020

Acceptance Criteria: \%RD $<0.012 ;$ mean SD $<0.006$

Data File/ Batch ID: $\quad$ Excel file: HIGH-PRECISION-CALC-Final for ORNL Qualification 06-15-2020

Criteria source: CSD-AM-NCL-INO2, NBL-SA-U(E)-2-2

Nominal standard concentration: $0.99975 \pm 0.00006(k=2)$

\begin{tabular}{|l|l|l|l|}
\hline Sample ID & Result (g U/g) & $\%$ RD & Acceptance \\
\hline 202000923 & 0.99976 & 0.0007 & Pass \\
\hline 202000924 & 0.99971 & -0.0044 & Pass \\
\hline 202000925 & 0.99973 & -0.0023 & Pass \\
\hline 202000926 & 0.99971 & -0.0042 & Pass \\
\hline 202000927 & 0.99973 & -0.0018 & Pass \\
\hline Mean & 0.99973 & -0.0024 & Pass \\
\hline SD & $2.1 \mathrm{E}-05$ & 0.0021 & Pass \\
\hline
\end{tabular}

Anaysten Rogers $3012236 \quad 6 / 19 / 2020$

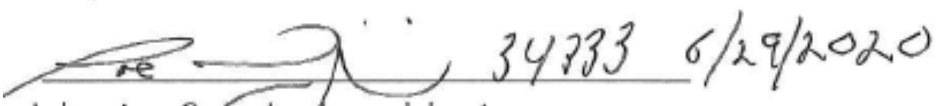

Laboratory Grøup Leader or delegate

Jennifer Parikh Digitally signed by Jennifer Parikh

Date: $2020.06 .2915: 31: 54-04^{\prime} 00^{\prime}$

Quality Representative 